Research Paper

\title{
Epicoccum nigrum and Cladosporium sp. for the treatment of oily effluent in an air-lift reactor
}

\author{
Daniel Delgado Queissada, Flávio Teixeira da Silva, Juliana Sundfeld Penido, \\ Carolina Dell'Aquila Siqueira, Tereza Cristina Brazil de Paiva \\ Departamento de Biotecnologia, Escola de Engenharia de Lorena, Universidade de São Paulo, \\ Lorena, São Paulo, Brazil.
}

Submitted: August 24, 2011; Approved: September 10, 2012.

\begin{abstract}
The metalworking industry is responsible for one of the most complex and difficult to handle oily effluents. These effluents consist of cutting fluids, which provide refrigeration and purification of metallic pieces in the machining system. When these effluents are biologically treated, is important to do this with autochthonous microorganisms; the use of these microorganisms (bioaugmentation) tends to be more efficient because they are already adapted to the existing pollutants. For this purpose, this study aimed to use two indigenous microorganisms, Epicoccum nigrum and Cladosporium sp. for metalworking effluent treatment using an air-lift reactor; the fungus Aspergillus niger (laboratory strain) was used as a reference microorganism. The original effluent characterization presented considerable pollutant potential. The color of the effluent was $1495 \mathrm{mg} \mathrm{Pt} / \mathrm{L}$, and it contained 59 $\mathrm{mg} / \mathrm{L} \mathrm{H}_{2} \mathrm{O}_{2}, 53 \mathrm{mg} / \mathrm{L}$ total phenols, $2.5 \mathrm{mgO}_{2} / \mathrm{L}$ dissolved oxygen (DO), and $887 \mathrm{mg} / \mathrm{L}$ oil and grease. The COD was $9147 \mathrm{mgO}_{2} / \mathrm{L}$ and the chronic toxicity factor was 1667 . Following biotreatment, the fungus Epicoccum nigrum was found to be the most efficient in reducing (effective reduction) the majority of the parameters $\left(26 \% \mathrm{COD}, 12 \% \mathrm{H}_{2} \mathrm{O}_{2}, 59 \%\right.$ total phenols, and $40 \%$ oil and grease), while Cladosporium sp. was more efficient in color reduction (77\%).
\end{abstract}

Key words: Epicoccum nigrum, Cladosporium sp., metalworking effluent, air-lift reactor.

\section{Introduction}

One of the biggest environmental impacts of effluents is the oils they contain. Of these oily effluents, those produced by the metalworking industry are some of the most abstruse and difficult to treat and reuse because of the high variety and the complexity of the compounds present in this type of effluent (Runge and Duarte, 1990). Among these systems used to treat oily effluents, biologics are the ones that provide greater economic flexibility to improvements that result in effective and economically viable solutions to the treatment of these wastes (Mariano, 2001).

Bacteria, yeasts and filamentous fungi have been cited in the literature as effective change agents due to their ability to degrade a variety of organic substances com- monly found in oily effluents (Tano-Debrah et al., 1999; Mendes et al., 2005; Van Der Merwe et al., 2005). However, the lack of specificity in biological treatment means that this type of process is also sometimes ineffective. To solve this problem, the best approach is to perform biological treatment with microorganisms isolated from the effluent itself (autochthonous) to be treated, because the treatment process with these microorganisms (bioaugmentation) tends to be more effective since they are already adapted to the pollutants it contains (Hururay et al., 1998).

Within this context, this work had as its main objective the treatment of a metalworking effluent with two autochthonous microorganisms, Epicoccum nigrum and Cladosporium sp., using the fungus A. niger (laboratory strain) as a reference microorganism.

Send corresponden to D.D. Queissada. Department of Biotechnology, Lorena Engineering School, University of São Paulo, Lorena, São Paulo, Brazil. E-mail: queissada@gmail.com. 


\section{Materials and Methods}

\section{Effluent}

We used the effluent from the demulsification step (oil-water separation) by acidification from the metalworking industry in the region of Vale do Paraiba in São Paulo State, Brazil. This step (demulsification) was performed by the industry for the removal of excess oil in the effluent. The watery part of the effluent after demulsification was collected so that the sample taken for the studies was representative of the whole. The total sample was $40 \mathrm{~L}$ (distributed into two $20 \mathrm{~L}$ bottles). The sampling volume was also divided in aliquots of $40 \mathrm{~mL}, 600 \mathrm{~mL}, 1.5 \mathrm{~L}$, and $3.5 \mathrm{~L}$, stored in plastic containers and kept in a cold chamber at $-18{ }^{\circ} \mathrm{C}$. However, prior to storage, separate $4 \mathrm{~L}$ bottles (divided into two 2 L bottles) were for set aside microorganism isolation. The isolation was performed through the technique pour-plate (Pelczar et al., 1997).

\section{Characterization of metalworking effluent}

\section{pH determination}

The $\mathrm{pH}$ of the effluent sample was determined using an Analion PM608 pH meter with an Analion V627 electrode.

\section{Color determination}

Color was measured according to modified CPPA standard methodology (CPPA, 1975). In all determinations, the samples were first centrifuged for $15 \mathrm{~min}$ at $10,500 \mathrm{rpm}$ and the $\mathrm{pH}$ was adjusted to 7.6 with $\mathrm{NaOH}$ $1 \mathrm{~mol} / \mathrm{L}$. The solution absorbance in the visible spectrum was determined at $465 \mathrm{~nm}$ against distilled water in a UV/VIS Hitachi U2000 spectrophotometer. The absorbance values were converted into milligrams of platinum per liter (mg Pt/L) according to Eq. (1).

$$
\text { Color }=500 \frac{\mathrm{A}_{1}}{\mathrm{~A}_{2}}
$$

where $\mathrm{A}_{1}=$ Absorbance of a platinum - cobalt standard solution of $500 \mathrm{mg} \mathrm{Pt} / \mathrm{L}, \mathrm{A}_{465}=0.132$ and $\mathrm{A}_{2}=$ Absorbance of the effluent, measured at $465 \mathrm{~nm}$.

\section{Hydrogen peroxide determination $\left(\mathrm{H}_{2} \mathrm{O}_{2}\right)$}

The hydrogen peroxide $\left(\mathrm{H}_{2} \mathrm{O}_{2}\right)$ concentration was determined according to the procedure adapted from Oliveira et al. (2001), based on the reaction between $\mathrm{H}_{2} \mathrm{O}_{2}$ and the metavanadate ion $\left(\mathrm{VO}_{3}^{-}\right)$. The reaction leads to the formation of ion peroxovanadate $\left(\mathrm{VO}_{3}+\right)$, which absorbs at $450 \mathrm{~nm}$. Calibration curves were prepared from aqueous solutions of $\mathrm{H}_{2} \mathrm{O}_{2}$, there being a linear response range between 5 and $200 \mathrm{mg} / \mathrm{L}$. For the determination, an aliquot of $1 \mathrm{~mL}$ of sample was added to $1 \mathrm{~mL}$ of ammonium metavanadate solution $\left(\mathrm{NH}_{4} \mathrm{VO}_{3}\right)$ under constant agitation, and after $2 \mathrm{~min}$, the absorbance was read at $450 \mathrm{~nm}$ on a
UV/VIS Hitachi U2000 spectrophotometer. The $\mathrm{H}_{2} \mathrm{O}_{2}$ concentration of the sample was obtained by interpolation of the absorbance measured in the sample, in the calibration curve.

Chemical oxygen demand (COD), total phenols (TF), oils and grease (O\&G) and dissolved oxygen (DO) determination

The COD, TF, O\&G and DO (Winkler method) determinations were performed according to methods described in APHA (1998).

\section{Chronic toxicity determination}

To determine the chronic toxicity, we used the green alga Pseudokirchneriella subcaptata; the determination followed the methodology NBR 12648/05 (ABNT, 2005).

\section{Biotreatment in an air-lift reactor}

Treatments were performed with the selected microorganisms Epicoccum nigrum and Cladosporium sp., and compared to treatment without inoculum (S/I), for the observation of the possible oxidation of compounds of the effluent arising from the oxygenation and photolysis. For this, the microorganisms were transferred to tubes containing PDA (Potato Dextrose Agar) and incubated for $120 \mathrm{~h}$ in the dark at $28{ }^{\circ} \mathrm{C}$. After this period, the culture was suspended in $10 \mathrm{~mL}$ of distilled water and autoclaved. Then, the cells were quantified in a Neubauer chamber, standardizing to a volume containing $10^{8}$ spores. Each aliquot of the suspension was added to the air-lift reactor, containing $350 \mathrm{~mL}$ of raw effluent, in triplicate, with the $\mathrm{pH}$ adjusted to 6.5 . The treatment was for 7 days at $28{ }^{\circ} \mathrm{C}$ and under a flow of air, previously filtered, $80-90 \mathrm{~mL} / \mathrm{min}$, controlled by rotameter. After treatment, the effluent was allowed to rest for $24 \mathrm{~h}$, and the aqueous phase was collected for the determination of the selected parameters after treatment. Figure 1 shows a schematic diagram of the reactor that was used in this experiment.

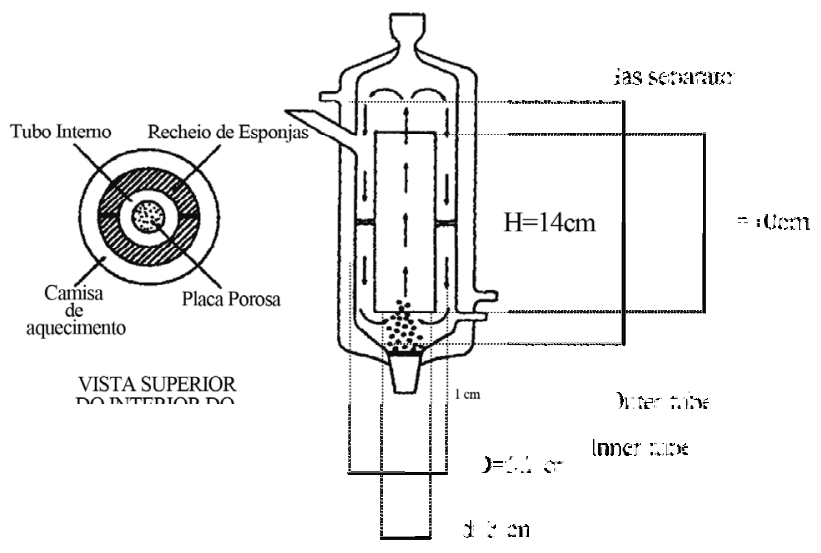

Figure 1 - Air-lift bioreactor. 


\section{Results and Discussion}

\section{Characterization of metalworking effluent}

The results of the physicochemical characterization of the effluent are presented in Table 1. The results indicate that this was a highly polluting effluent, due to the high acidity $(\mathrm{pH} 1.7 \pm 0.1)$ and coloration $(1495 \pm 149 \mathrm{mg} \mathrm{Pt} / \mathrm{L})$.

The coloration was associated with chromophore compounds present in the effluent. Disposal of this effluent may be harmful to the receiving body of water, since it increases the blockage of light, which consequently affect photosynthesis, and also hinders the transfer of atmospheric oxygen into the aquatic environment, thus reducing the dissolved oxygen content (CETESB, 2009).

The high COD $(9147 \pm 514 \mathrm{mg} / \mathrm{L})$ was attributed to the presence of a high content of dissolved organic matter. Several authors have described metalworking effluents to have high COD values. Cheng et al. (2006) determined a COD of $8,000 \mathrm{mg} / \mathrm{L}$ in a metalworking effluent. Van der Gast and Thompson (2004) found a COD of approximately $10,000 \mathrm{mg} / \mathrm{L}$ in a similar effluent. Monteiro (2006) characterized a metalworking effluent similar to the one used in the present study and determined a COD of approximately $3,700 \mathrm{mg} / \mathrm{L}$. Oily effluents generally have complex and highly variable characteristics, whether physical, chemical or biological, and their decomposition increases the COD, thus reducing the $\mathrm{OD}$, and causes harmful changes in aquatic ecosystems (CETESB, 2009).

Hydrogen peroxide $\left(\mathrm{H}_{2} \mathrm{O}_{2}\right)$ was found at a concentration of $59 \pm 1 \mathrm{mg} / \mathrm{L}$. Its presence in this effluent type is common because it is used as a fungicide and bactericide in cutting oils to prevent the contamination of the cutting fluid (Canter, 2008; Peres et al., 2008).

The high concentration of total phenolics (5.4 \pm $0.4 \mathrm{mg} / \mathrm{L}$ ) was a limiting characteristic of the effluent, since under CONAMA (2012) resolution 430/11, the maximum permitted concentration is $0.5 \mathrm{mg} / \mathrm{L}$. The toxicity of phe-

Table 1 - Physico-chemical properties of the effluent.

\begin{tabular}{lcc}
\hline Parameters & Results & Standard* \\
\hline Temperature & $25^{\circ} \mathrm{C}^{* *}$ & $<40{ }^{\circ} \mathrm{C}$ \\
$\mathrm{pH}$ & $1.7 \pm 0.1^{*}$ & $5-9$ \\
Color $(\mathrm{mg} \mathrm{Pt} / \mathrm{L})$ & $1.495 \pm 149^{*}$ & 75 \\
$\mathrm{COD}(\mathrm{mg} / \mathrm{L})$ & $9.147 \pm 514$ & $\mathrm{ND}$ \\
$\mathrm{H}_{2} \mathrm{O}_{2}(\mathrm{mg} / \mathrm{L})$ & $59 \pm 1$ & $\mathrm{ND}$ \\
$\mathrm{Total} \mathrm{phenols}(\mathrm{mg} / \mathrm{L})$ & $5.4 \pm 0.4^{*}$ & 0.5 \\
$\mathrm{DO}(\mathrm{mg} / \mathrm{L})$ & $2.5 \pm 0.2^{*}$ & $\geq 5$ \\
O\&G (mg/L) & $887 \pm 55^{*}$ & 20 \\
$\mathrm{C}$. Tox $(\mathrm{Tox}$. factor $)$ & 1667 & $\mathrm{ND}$ \\
\hline
\end{tabular}

* - value not allowed by federal and state legislation.

** - value allowed by legislation.

ND - Value not defined in legislation. nolic compounds in oily effluents has been extensively studied and it is well-established that the presence of these contaminants at levels of $\mathrm{mg} / \mathrm{L}$ significantly impairs the receiving body of water (Guerra, 2001). Moreover, the phenolic pollutants may also cause toxicity to the microorganisms used in biological treatment systems of oily effluents (Mishra et al., 1995).

The industrial effluents usually contain more than one type of pollutant phenolic, and those with more complex structures are often more toxic than the phenol molecule (Zhou and Fang, 1997). Another undesirable characteristic of these contaminants is the fact that they can react with chlorine, producing chlorophenols and polychlorophenols, which are carcinogenic compounds (Colarieti et al., 2002).

The low concentration of DO $\left(2.5 \pm 0.2 \mathrm{mg} \mathrm{O}_{2} / \mathrm{L}\right)$ was certainly related to the high COD, which consequently reduces the DO concentration, a common characteristic of oily effluents. Ekundayo and Fodeke (2000) determined a DO of $5 \mathrm{mg} / \mathrm{L}$ in a receiving tank of various oily effluents, including those from the metalworking industry. Ferreira $e t$ $a l$. (2000) found an DO less than $1 \mathrm{mg} / \mathrm{L}$ in an untreated effluent from an oil refinery, while Conceição et al. (2005) detected a higher level of DO in a refinery oily effluent, at a level of approximately $7 \mathrm{mg} / \mathrm{L}$, thus showing that the DO level is quite variable in different oily effluents generated by different industries.

In this work, we also determined the O\&G concentration $(887 \pm 55 \mathrm{mg} / \mathrm{L})$, which, according to the methodology in item 2.4.8., are associated with soluble substances in $\mathrm{n}$-hexane. These substances include fatty acids, animal fats, soaps, greases, oils, waxes, and mineral oils (CETESB, 2009). Similar results of the O\&G concentration in oily effluents are reported in the literature. Damato et al. (1997) reported $871 \mathrm{mg} / \mathrm{L}$ of $\mathrm{O} \& \mathrm{G}$ in an effluent containing cutting fluid. In another study, Tessaro (2008) found a concentration of $9942 \mathrm{mg} / \mathrm{L}$ of O\&G in a metalworking effluent. Furthermore, Schoeman and Novhe (2007) worked with a similar effluent, and determined a concentration of 19,794 mg/L.

The high O\&G value and the effluent color, but also the low $\mathrm{DO}$ value and $\mathrm{pH}$, led to an initial interpretation that the effluent could be highly toxic. That was confirmed by the results of the chronic toxicity test on the green alga Pseudokirchneriella subcaptata, which showed a toxicity factor (ToxF) of 1667. Generally, algae are 50\% more sensitive than invertebrates and fish in toxicological studies using industrial effluents (Hartmann, 2005). Monteiro (2006) observed a ToxF of approximately 1,300 when conducting chronic toxicity tests with $P$. subcaptata using the same type of effluent.

\section{Biotreatment in an air-lift reactor}

This stage of the work involved treatment with the selected microorganisms (E. nigrum and Cladosporium sp.) and treatment without inoculum (W/I) to observe a possible 
contribution of compound oxidation due to photolysis and aeration in the treatment system.

The aim of the study was to assess which microorganism was more effective in the treatment of wastewater from the cutting fluid, using an oxygenated (air-lift) system. The advantages of using an "air-lift" reactor are the simplicity of the equipment, thus facilitating its handling, the decrease of shear to cells, thus avoiding their disruption, good mixing and better asepsis during long operations, due to the elimination of a stem shaker (Gouveia et al., 2000).

The treatments lasted for 7 days, containing $350 \mathrm{~mL}$ of effluent with the $\mathrm{pH}$ adjusted to 6.5 and $28^{\circ} \mathrm{C}$. The results of these treatments are shown in Tables 2 and 3.

The treatment without inoculum (W/I) reduced $\mathrm{H}_{2} \mathrm{O}_{2}$ to $92 \pm 2 \%$ and increased the DO to $228 \pm 3 \%$. The $\mathrm{H}_{2} \mathrm{O}_{2}$ consumption was possibly brought about by photolysis, due to the natural light that the reactor received during treatment. The dissolved oxygen increase in the sample after treatment was expected since $\mathrm{O}_{2}$ was added during the process; additionally, this may have increased through $\mathrm{H}_{2} \mathrm{O}_{2}$ decomposition (Suznjevic et al., 1997). The treatment without inoculum still reduced the sample color by $10 \pm 2 \%$; this may have occurred by the destruction of chromophore groups and/or mineralization of organic compounds, respectively, by hydroxyl radicals formed by the possible decomposition of $\mathrm{H}_{2} \mathrm{O}_{2}$ (Mattos et al., 2003). However, in relation to other determined parameters after treatment, the system without inoculum did not have a significant influence.

Table 3 presents the results obtained with biological treatment in the air-lift reactor with autochthonous fungi in the effluent (E. nigrum and Cladosporium sp.) and the reference fungus $A$. niger.

Following wastewater treatment in the air-lift reactor, it was observed that the $\mathrm{pH}$ effectively increased on average by $10 \pm 2 \%$ after treatment. This increase in $\mathrm{pH}$ may be associated with the decomposition of fatty acids present in the sample, by the enzymatic action of fungi (Mendes et al., 2005).

Table 2 - Post-treatment parameters in the air-lift bioreactor in effluent without inoculum (W/I).

\begin{tabular}{lcc}
\hline Parameters post-treatment & Value & Reduction (\%)** \\
\hline $\mathrm{pH}$ & $6.4 \pm 0.1$ & $2 \pm 2$ \\
Color (mg Pt/L) & $1345 \pm 15$ & $10 \pm 2$ \\
$\mathrm{COD}(\mathrm{mg} / \mathrm{L})$ & $9056 \pm 54$ & $1 \pm 1$ \\
$\mathrm{H}_{2} \mathrm{O}_{2}(\mathrm{mg} / \mathrm{L})$ & $4.7 \pm 0.1$ & $92 \pm 2$ \\
Total phenols (mg/L) & $5.2 \pm 0.2$ & $4 \pm 4$ \\
DO (mg/L) & $8.2 \pm 0.1$ & $228 \pm 3^{*}$ \\
O\&G (mg/L) & $860 \pm 18$ & $3 \pm 2$ \\
C. Tox (Tox. factor) & 1634 & 2 \\
\hline
\end{tabular}

* - percentage increase.

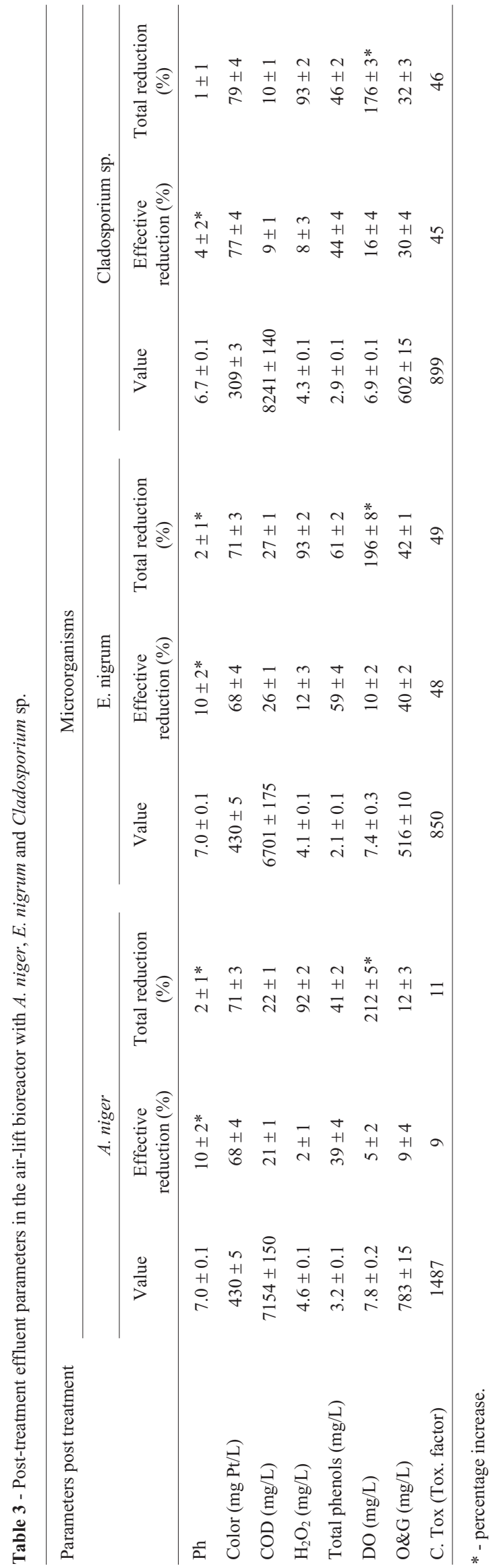


The effective color reduction was similar with the three fungi. Using Cladosporium sp., the reduction was $77 \pm 4 \%$, while for $E$. nigrum and A. niger this was $68 \pm 4 \%$.

The effective COD reduction was more significant when the effluent was treated using E. nigrum, with a $26 \pm 1 \%$ reduction. Using the reference fungus $A$. niger, this reduction was smaller, reaching $21 \pm 1 \%$. Van der Merwe $e t$ al. (2005) studied the biological treatment of oily effluents, with a $\mathrm{pH}$ around 5.5 and a temperature of $30^{\circ} \mathrm{C}$. However, these authors inoculated the effluent with a fungal consortium, and achieved a maximum COD reduction of $51 \%$.

The effective $\mathrm{H}_{2} \mathrm{O}_{2}$ reduction was more intense using the fungus $E$. nigrum $(12 \pm 3 \%)$, while $A$. niger had virtually no effect on reducing this parameter.

In all treatments with the autochthonous microorganisms, the concentration of total phenolics (TP) in the effluent achieved reductions above $40 \%$. The microorganism $E$. nigrum caused the greatest reduction (59 $\pm 4 \%$ ), compared to $44 \pm 4$ and $39 \% \pm 4 \%$ achieved with Cladosporium sp. and $A$. niger, respectively.

It was observed that the treatment without inoculum was associated with an increase in DO, possibly due to the addition of the same during treatment. However, taking into account treatment with the microorganisms, reductions in DO levels were seen at the end of treatment. Treatment with the fungus Cladosporium sp., with more effective consumption of oxygen, reduced the DO concentration by $16 \pm$ $4 \%$. However, when treatment was performed with the fungi E. nigrum and A. niger, the DO of the effluent was effectively reduced by $10 \pm 2 \%$ and $5 \pm 2 \%$ respectively.

The treatments performed with the effluent autochthonous microorganisms were also more effective in $O \& G$ reduction than the treatment that used the reference fungus A. niger. Using E. nigrum and Cladosporium sp., the effective reductions were $40 \pm 1 \%$ and $30 \pm 4 \%$, respectively. However, with $A$. niger, the effective reduction was only $9 \pm 4 \%$.

This possibly occurred due to autochthonous microorganisms are already adapted to the effluent under study. Tano-Debrah et al. (1999) treated a sample of oily effluent for 7 days at $30^{\circ} \mathrm{C}$ and $\mathrm{pH} 7$, with the inoculation of $5 \times 10^{8}$ spores $/ \mathrm{mL}$ of different microorganisms (no identification) and obtained $86 \%$ O\&G degradation, increasing the DO of the sample by $30 \%$ and reducing its COD to $60 \%$.

E. nigrum and Cladosporium sp. also effectively and more significantly reduced the chronic toxicity (C. Tox.) of the effluent compared to the reference microorganism $A$. niger. While E. nigrum and Cladosporium sp. effectively reduced the $C$. Tox. to $48 \%$ and $45 \%$, respectively, A. niger reached an effective reduction of $9 \%$. We observed that the effective chronic toxicity reductions achieved by the three fungi (A. niger, 9\%; E. nigrum, $48 \%$ and Cladosporium sp., $45 \%$ ) were similar when compared with the effective reductions in oils and greases $(9 \pm 4 \%, 40 \pm 2 \%$ and $30 \pm 4 \%)$.
Therefore, the oil and grease constituents of the effluent may be one of the main factors that determine the chronic toxicity.

\section{Conclusion}

The characterization of crude oily wastewater showed that, in terms of the determined parameters, it had a high pollution potential. Biotreatment in an air-lift type reactor reduced all determined parameters, except $\mathrm{pH}$, which increased on average by $10 \%$. The fungus Epicoccum nigrum was more effective in reducing most of the determined parameters (COD, $\mathrm{H}_{2} \mathrm{O}_{2}$, TP, O\&G and C. Tox.). However, Cladosporium sp. was more effective in color reduction. These are, therefore, microorganisms with a high potential to reduce pollution-related parameters in this effluent type compared with the reference microorganism $A$. niger.

\section{Acknowledgments}

The authors thank FAPESP for the financial support and Lucia C. B. Castro for the essential technical support.

\section{References}

ABNT - Associação Brasileira de Normas Técnicas. (2005). NBR 12648: Ecotoxicologia aquática - Método de ensaio com algas (Chlorophyceae). Rio de Janeiro.

APHA - Standard Methods for the Examination of Water and Wastewater. (1998). American Public Health Association, Washington D.C.

Canter N (2008) Waste treatment of chlorinated phenolic biocides. Tribol Lubric Tech October 18-19.

CETESB - Companhia de Tecnologia de Saneamento Ambiental (2009). Qualidade das Águas Interiores no Estado de São Paulo. Série Relatórios. Apêndice A - Significado Ambiental e Sanitário das Variáveis de Qualidade das Águas e dos Sedimentos e Metodologias Analíticas e de Amostragem, 19-20.

Cheng C, Phipps D, Alkhaddar RM (2006) Thermophilic aerobic wastewater treatment of waste metalworking fluids. Water Environ J 20:227-232.

Colarieti ML, Toscano G, Greco JRG (2002) Soil-catalyzed polymerization of phenolics in polluted waters. Water Res 36:3015-3022.

Conselho Nacional do Meio Ambiente. (2012) Resolução $n^{\circ}$ 430/11. Available at: http://www.mma.gov.br. Accessed 21 Jun 2012.

Conceição DM, De Angelis DA, Bidoia ED, De Angelis DF (2005) Fungos filamentosos isolados do Rio Atibaia, SP e refinaria de petróleo biodegradadores de compostos fenólicos. Arqu Inst Bio Junho 99-106.

CPPA - Canadian Pulp and Paper Association. (1975). Technical Section Standart Test Methods, H5P, Montreal.

Damato M, Sobrinho PA, Morita DM (1997) Determinação da toxicidade aguda de efluentes de refinaria de petróleo em diversas etapas de tratamento para Dapnia similis. Congresso Brasileiro de Engenharia Sanitária e Ambiental, Foz do Iguaçu, PR, pp 119. 
Ekundayo EO, Fodeke VO (2000) Microbial densities and physico-chemical quality of some crude oil flowstations saver pit effluents in the Niger delta basin of Southern Nigeria. Environ Monit Assess. 65:523-530.

Ferreira EFT, Almeida JHC, Santiago VMJ, Wachburger RL (2000) Ampliação da estação de tratamento de despejos industriais (EDTI) da refinaria Alberto Pasqualini (REFAP) da Petrobras. XXVII Congresso Interamericano de Engenharia Sanitária e Ambiental, Porto Alegre, RS, p. 1.

Gouveia ER, Hokka CO, Badino AC (2000) Estudos hidrodinâmicos e de transferência de oxigênio em bioreator air-lift. XIII Simpósio Nacional de Fermentações, Teresópolis, RJ, CD ROM.

Guerra R (2001) Ecotoxicological and Chemical Evaluation of Phenolic Compounds in Industrial Effluents. Chemosphere, 44:1737-1747.

Hartmann CC (2005) Avaliação de um efluente industrial através de ensaios ecotoxicológicos e análises físicas e químicas. Porto Alegre, Brasil, p. 85 (M.Sc. Dissertation. Departamento de Ecologia. UFRGS).

Hururay AFP, Pereira Junior N, Marins MDM (1998) Desempenho de um bioreator do tipo CSTR no processo de degradação de borra oleosa. Petrobrás, Rio de Janeiro.

Mariano JB (2001) Impactos ambientais do refino de petróleo. Rio de Janeiro, Brasil, p.279 (Ph.D Thesis. Departamento de Engenharia. UFRJ).

Mattos IL, Shiraishi KA, Braz AD, Fernandes JR (2003) Peróxido de hidrogênio: Importância e determinação. Quím Nova 26:373-380.

Mendes AA, Castro HF, Pereira EB, Furigo JRA (2005) Aplicação de lipases no tratamento de águas residuárias com elevados teores de lipídeos. Quím Nova 28:296-305.

Mishra VS, Mahajani VV, Joshi JB (1995) Wet air oxidation. Ind Eng Chem Res 34:2-48.

Monteiro MI (2006) Tratamento de efluentes oleosos provenientes da indústria metal-mecânica e seu reuso. Lorena, Brasil, p.148 (Ph.D Thesis. Departamento de Biotecnologia Industrial. USP).
Oliveira MC, Nogueira RFP, Gomes Neto JÁ, Jardim WF, Rohwedder JJR (2001) Sistema de injeção em fluxo espectrofotométrico para monitorar peróxido de hidrogênio em processo de fotodegradação por reação foto-fenton. Quím Nova 24:188-190.

Peres FAZ, Teixeira LAC, Yokoyama L, Campos JC, Miguel MAL (2008) Tratamento de águas de refrigeração com peróxido de hidrogênio. Quím Nova 31:1851-1855.

Pelczar MJJR, Chan ECS, Krieg NR (1997) Microbiologia: Conceitos e aplicações, $2^{\text {th }}$ ed. São Paulo: Ed. Makron Books, v. 1, 556 pp.

Runge PRF, Duarte GN (1990) Lubrificantes nas indústrias produção, manutenção e controle. Ed. Triboconcept, Cotia.

Schoeman JJ, Novhe O (2007) Evaluation of microfiltration for the treatment of spent cutting-oil. Water SA 33:245-248.

Suznjevic D, Blagojevic S, Vucelic D, Zuman P (1997) Polarographic determination of hydrogen peroxide in perborate containing commercial detergents under the bleaching process condition. Electroanalysis, 9:861-864.

Tano-Debrah K, Fukuyama S, Otonari N, Taniguchi F, Ogura M (1999) An inoculum for the aerobic treatment of wastewaters with high concentrations of fats and oils. Biores Techn 69:133-139.

Tessaro EP (2008) Avaliação de processos oxidativos para o tratamento ambiental adequado de fluidos de corte. São Carlos, Brasil, p.96 (M. Sc. Dissertation. Departamento de Química. USP).

Van Der Gast CJ, Thompson IP (2004) Effects of pH amendment on metal working fluid wastewater biological treatment using a defined bacterial consortium. Biotech Bioengin 89:357-366.

Van Der Merwe R, Badenhorst J, Britz TJ (2005) Fungal treatment of an edible oil containing industrial effluent. W J Microbiol Biotechnol 21:947-953.

Zhou G, Fang HHP (1997) Co-degradation of phenol and m-cresol in a UASB reactor. Biores Techn 61:47-52.

All the content of the journal, except where otherwise noted, is licensed under a Creative Commons License CC BY-NC. 